\title{
Potential Benefits of Boswellia sacra Resin on Immunity, Metabolic Status, Udder and Uterus Health, and Milk Production in Transitioning Goats
}

\author{
Nesrein M. Hashem ${ }^{1, *(1)}$, Amr S. Morsy ${ }^{2}$, Yosra A. Soltan ${ }^{1}$ and Sobhy M. Sallam ${ }^{1}$ \\ 1 Department of Animal and Fish Production, Faculty of Agriculture, Alexandria University, \\ Alexandria 21545, Egypt; yosra.soltan@alexu.edu.eg (Y.A.S.); soubhy.salam@alexu.edu.eg (S.M.S.) \\ 2 Livestock Research Department, Arid Lands Cultivation Research Institute, City of Scientific Research and \\ Technological Applications (SRTA-City), New Borg El-Arab, Alexandria 21934, Egypt; amorsy@srtacity.sci.eg \\ * Correspondence: nesreen.hashem@alexu.edu.eg
}

Citation: Hashem, N.M.; Morsy, A.S.; Soltan, Y.A.; Sallam, S.M. Potential Benefits of Boswellia sacra Resin on Immunity, Metabolic Status, Udder and Uterus Health, and Milk Production in Transitioning Goats. Agriculture 2021, 11, 900. https:// doi.org/10.3390/agriculture11090900

Academic Editor: Nicole Kemper

Received: 12 August 2021

Accepted: 15 September 2021

Published: 18 September 2021

Publisher's Note: MDPI stays neutral with regard to jurisdictional claims in published maps and institutional affiliations.

Copyright: () 2021 by the authors. Licensee MDPI, Basel, Switzerland. This article is an open access article distributed under the terms and conditions of the Creative Commons Attribution (CC BY) license (https:// creativecommons.org/licenses/by/ $4.0 /)$.

\begin{abstract}
As an attempt to prevent transition-period-associated metabolic disorders and/or diseases, the potential benefits of Boswellia sacra (Bs) resin on hematology, immunity, metabolic status, udder and uterus health biomarkers, and milk production were examined in transitioning goats. From 2 weeks prepartum to 7 weeks postpartum, goats ( $n=7 /$ treatment) orally received 0 (control, nBS), 2 (BsL), or 4 (BsH) g of Bs resin/goat/day. The results showed that both Bs treatments significantly improved the activity of phagocytes. Both Bs treatments significantly decreased the concentrations of blood plasma urea, non-esterified fatty acids, hydroxybutyric acid, and interleukin- $1 \beta$, whereas they increased the total antioxidant capacity compared with the nBS treatment. Both Bs treatments significantly decreased the uterine horn diameter and tended to decrease the intrauterine fluid content, indicating improved uterine involution compared with no treatment. Compared with the nBS treatment, both Bs treatments significantly decreased the milk somatic cell count. The lowest milk interleukin-1 $\beta$ content was observed in goats that received the BsL treatment, followed by those that received the BsH and nBS treatments. The BsL treatment significantly increased the concentration of immunoglobulin $\mathrm{M}(\mathrm{IgM})$ in the colostrum compared with the other treatments. Both Bs treatments significantly increased the daily milk yield compared with the nBS treatment but did not affect milk composition or the fat-to-protein ratio. In conclusion, supplementing lactating goats in the transition period with Bs resin at a dose of $2 \mathrm{~g} /$ goat/day positively affected the body lipid metabolism, udder and uterus health, colostrum $\operatorname{IgM}$ content, and milk yield due to its antioxidant and anti-inflammatory effects.
\end{abstract}

Keywords: lactating goats' welfare; metabolic status; immunity; uterine involution; milk production

\section{Introduction}

Ensuring the maintenance of food producing animals health and disease prevention during their production life is a crucial farm practice that fulfils both animal welfare aspects and minimizes outbreak of zoonotic diseases, matching the approach of the One Health concept. In ruminants, the transition period (late gestation to early lactation) is accompanied by many metabolic, physiological, and behavioral adaptive mechanisms to meet the requirements of the postpartum period, including lactogenesis, uterine involution, and ovarian resumption [1,2]. These dramatic changes increase the vulnerability of lactating animals to metabolic disorders and infectious diseases due to the increase in inflammatory factors, free radicals, and impaired immunity [3-5], which may increase the risk of disease emergence among and via food-producing animals. Thus, the productivity and health status of postpartum dams are due to the sum of interactions between metabolic status, immune system function, and inflammatory status [6]. For example, pathogenic diseases and clinical and/or subclinical inflammatory states can be evoked in the postpartum period 
as a response to endometrial damage during parturition and relaxation of the cervix during parturition, facilitating microbial invasion [7]. Besides, the severe energy utilization by the mammary gland can lead to negative energy balance (NEB) and insulin resistance, which increase the risk of developing metabolic diseases, such as ketosis. These metabolic diseases can induce certain immune system depression and increase inflammatory factors [4]. Accordingly, the productivity and health status of transitioning dams during the postpartum period could be boosted by adjusting their metabolism and immunity.

Nowadays, there is growing interest regarding the use of phytogenic active compounds as feed additives due to their impressive and wide biological activities and their safety for human and animal health. Among the promising sources of phytogenic bioactive compounds, the Boswellia genus has countless pharmacological activities. The Boswellia genus includes approximately 25 distinct species of which Boswellia sacra and Boswellia serrata are the most common species used for pharmacological, prophylactic, and therapeutic purposes [8]. Several biologically active compounds were found in various Boswellia species, including resins (60-85\%; mixtures of pentacyclic triterpenes mainly boswellic acid), gums (6-30\%; mixture of pentose and hexose), and essential oil (5-9\%; mixture of monoterpenes, diterpenes, and sesquiterpenes) $[9,10]$. This wide range of bioactive components confers several biological properties to the Boswellia species, including anti-inflammatory, antiarthritic, antirheumatic, antidiarrheal, antihyperlipidemic, anti-asthmatic, anticancer, antimicrobial, antifungal, anticomplementary, and analgesic activities [8,11,12]. Due to these characteristics, the Boswellia species is considered a conceivable candidate for improving productivity and health status of transitioning animals as the pharmacological activities of the Boswellia species, specifically anti-inflammatory, antimicrobial, and immunomodulatory effects, could be beneficial. The most important is that these benefits for the hygiene of dairy animals during the transition period might minimize the use of medications, specifically antibiotics, reducing antibiotic resistance crisis. Therefore, this study was conducted to investigate the potential benefits of Boswellia sacra (Bs) resin on the hematology, immunity, metabolic status, udder and uterus health biomarkers, and milk production in transitioning goats.

\section{Materials and Methods}

\subsection{Plant Material and Gas Chromatographic-Mass Spectral (GC-MS) Analysis}

A commercially available Boswellia sacra Flueck (Bs) gum resin was obtained from a local market (Omani Luban, Shathari, Dowkah Valley, Oman). The Bs was authenticated by the Plant Protection and Biomolecular Diagnosis Department, SRTA-City, New Borg El-Arab, Egypt. To identify the bioactive components of Bs, a $10 \mathrm{~g}$ sample of Bs was grounded through a $0.25 \mathrm{~mm}$ screen to obtain a fine powder. The powder was extracted using $100 \mathrm{~mL}$ ethanol $(70 \%, w / v)$ for $48 \mathrm{~h}$ at $51^{\circ} \mathrm{C}$. The mixture was filtered using a filter paper (Whatman No. 1, Camlab, Cambridge, UK). The filtrate (extract) was evaporated (RE301, Yamato Scientific America, Santa Clara, CA, USA) at $45^{\circ} \mathrm{C}$. The residual material was dissolved in high-grade ethanol. A gas chromatographic-mass spectral (GC-MS) analysis was performed on the extract using a Thermo Scientific TRACE-1300 series gas chromatography coupled with a Triple Quadrupole Mass (TSQ 8000 Evo; electron energy = 70 Ev; scan range $=40-700 \mathrm{amu}$; and scan rate $=5 \mathrm{scans} / \mathrm{s}$ ) and fitted using a fused silica capillary column (DB-5, $30 \mathrm{~m} \times 0.32 \mathrm{~mm}$ id; film thickness, $0.25 \mu \mathrm{m}$ ). The carrier gas was helium with a flow rate of $1 \mathrm{~mL} / \mathrm{min}$, and $10 \mu \mathrm{L}$ of the extract was injected using a splitless injection technique. The active components of the Bs extract were identified based on their retention indices and by comparing their mass spectral fragmentation patterns with those available in the main library. 


\subsection{Animals and Experimental Design}

This study was conducted at the Agricultural Experimental Station $\left(31^{\circ} 20^{\prime} \mathrm{N}, 30^{\circ} \mathrm{E}\right)$, Department of Animal and Fish Production, Faculty of Agriculture, Alexandria University, Egypt. All procedures and experimental protocols were approved by the Declaration of Pharmaceutical and Fermentation Industries Development Center and approved by the Institutional Animal Care and Use Committee (IAUCUs) of SRTA-city (protocol code: IAUCU \#37-6F-1021).

Twenty-one clinically healthy Egyptian Nubian (Zaraiebi) late pregnant goats, with a bodyweight of $29.75 \pm 0.97 \mathrm{~kg}$ and age of $46.42 \pm 1.74$ months, were used in this study. The goats were managed as one flock and kept outdoors with shelter during the day and housed in a semi-open barn at night. Each goat was fed a total mixture ration (TMR) diet, containing (g/kg diet): 400 Trifolium alexandrinum hay, 300 soybean meal, 200 maize, 125 wheat bran, 125 cottonseed meal, 100 wheat straw, $10 \mathrm{NaCl}$, and $5 \mathrm{CaCo}_{3}, 5$ premix. The chemical composition of the TMR diet was $97.3 \%$ dry matter, $90.4 \%$ organic matter, $13.7 \%$ crude protein, and $49.4 \%$ neutral detergent fiber, and the calculated metabolizable energetic content of the ration was $10.34 \mathrm{MJ} / \mathrm{kg}$ DM $[13,14]$. All goats were synchronized for estrus using a double- $\mathrm{PGF}_{2 \alpha}$ (Estrumate; $250 \mathrm{mg} / \mathrm{mL}$ cloprostenol; Vet Pharma, Friesoythe, Germany) injection, 11 days apart, and thus they gave births within a narrow period of time (a 2-day interval). Before 2 weeks of the expected kidding date, the goats were blocked considering their previous milk yield (1176 $\pm 146 \mathrm{~g} /$ day $)$ and parties $(2.78 \pm 0.72)$ and then allocated into three homogenous experimental groups. Goats orally received 0 (control, nBS), 2 (BsL), or 4 (BsH) g of Bs/goat/day. The Bs risen was prepared by steeping the Bs resin in warm water overnight; then, the mixture of Bs and water was vigorously shaken until forming a homogenous suspension. Each goat in the control group received $5 \mathrm{~mL}$ of water (placebo), while those in treatment groups received the same quantity of water containing the desired Bs dose planned for each treatment group. The treatment started 2 weeks prepartum and lasted 7 weeks postpartum. The goats were weighed one week postpartum, and seven weeks postpartum, the goats were fed with TMR to meet the nutrient requirements according to National research council recommendations [13]. Weekly adjustments were made to the weight of the TMR to ensure the collection of residuals during the experimental period. All kids $(1.33 \pm 0.113 \mathrm{kid} /$ treatment $)$ were reared with their dams during the experimental period, with the exception of the days of milk collection. The kids had no access to dam feeds but had free access to water. Goats and their kids had free access to fresh water.

\subsection{Determination of Hematobiochemical and Immunological Signs}

At weeks 1, 3, 5, and 7 postpartum (days 7, 21, 35, and 42 postpartum), blood samples were collected from each goat into $10 \mathrm{~mL}$ heparinized tubes via jugular venipuncture. A whole blood sample was used to determine hematological variables. Erythrocyte (RBC) count, leukocyte (WBC) count and types, and hematocrit values (Ht) were determined [15] Hemoglobin $(\mathrm{Hb})$ concentration was assessed using a colorimetric method using commercial kits (Reactivos GPL, Barcelona, Spain).

Phagocytic activity (PA) and phagocytic index (PI) were determined [16,17]. A whole blood sample was mixed (1:1) with Staphylococcus albus $\left(1.0 \times 10^{5}\right.$ cells $\left./ \mathrm{mL}\right)$ in phosphate buffer solution (PBS) $(\mathrm{pH}=7.2)$ and incubated for $30 \mathrm{~min}$ at $37^{\circ} \mathrm{C}$. A smear of the mixture was prepared and left until dry. The smear was fixed with methanol for $30 \mathrm{~min}$, then stained with Levowitz-Weber stain for $2 \mathrm{~min}$ and washed three times with distilled water. Phagocytic cells and engulfed bacteria were counted at $100 \times$ using a light microscope, and the PA and PI were calculated as follows: PA = percentage of phagocytic cells containing bacterial cells, and PI = the number of bacterial cells phagocytosed/number of phagocytic cells.

To obtain plasma for determining bactericidal activity (BA), lysozyme activity (LA), interleukin (IL)-11 $\beta$, and blood metabolites, blood samples were centrifuged at $2000 \times g$ for $15 \mathrm{~min}$. The BA of plasma against Aeromonas hydrophila was determined according 
to Calder [16] and Rainger and Rowley [18]. Briefly, $300 \mu \mathrm{L}$ of $A$. hydrophila suspension $\left(1.5 \times 10^{3}\right.$ cells $\left./ \mathrm{mL}\right)$ and $300 \mu \mathrm{L}$ of fresh plasma were mixed in a sterile tube. A blank consisting of $300 \mu \mathrm{L}$ of bacterial suspension and $300 \mu \mathrm{L}$ of sterile PBS was also prepared. The tubes were incubated at $28^{\circ} \mathrm{C}$. A $50 \mu \mathrm{L}$ sample was removed at $0,1,2,3$, and $4 \mathrm{~h}$ and cultured on a nutrient agar for $24 \mathrm{~h}$ at $28^{\circ} \mathrm{C}$. The colony-forming units (CFUs) were counted. The results were recorded as survival index (SI). The equation was as follows: $\mathrm{SI}=\mathrm{CFU}$ at the end $/ \mathrm{CFU}$ at the start $\times 100$. The plasma LA was determined by using lyophilized Micrococcus lysodeikticus as the substrate in PBS $(\mathrm{pH}=6.4)$. Then, $50 \mu \mathrm{L}$ of plasma was added to $3 \mathrm{~mL}$ of bacterial suspension. The absorbance of the mixture was measured at $570 \mathrm{~nm}$ twice, directly after plasma addition (Ao) and again after incubation (A) of the mixture for $30 \mathrm{~min}$ at $37^{\circ} \mathrm{C}$. The LA was calculated using the following formula: $\mathrm{LA}=(\mathrm{Ao}-\mathrm{A}) / \mathrm{A}[16]$. The concentration of blood plasma IL-1 $\beta$ was determined using a goat IL-1 $\beta$ ELISA kit (Cat. No. MBS262525, MyBioSource, San Diego, CA 92195-3308, USA). The sensitivity of the method was $5 \mathrm{pg} / \mathrm{mL}$, the intra- and inter-assay precisions were $\geq 8 \%$ and $\geq 12 \%$, respectively. In addition, the blood plasma samples were analyzed for total protein, albumin, glucose, cholesterol, and urea using colorimetric kits (Biosystems S.A., Costa Brava, Barcelona, Spain).

The plasma non-esterified fatty acids (NEFAs) and beta-hydroxybutyric acid (DiaSys Diagnostic Systems, Holzheim, Germany) were also determined. The plasma total antioxidant capacity (TAC) and malondialdehyde concentration (MDA) were determined using kits obtained from Biodiagnostic (Giza, Egypt).

\subsection{Determination of Udder and Uterus Health Bioindicators}

The somatic cells milk analyzer Ekomilk SCAN (Bulteh 2000, Stara Zagora, Bulgaria) was used to determine the number of somatic cells in each milk sample. To verify the results of the somatic cell count in goat milk, results of the analyzer were firstly calibrated by comparing the values of the analyzer with the values obtained from a microscopic count [19]. In order to normalize the results of somatic cell count, the values of somatic cell count were subjected to a linear somatic cell score transformation using Lithe formula: $3+\log _{2}$ (somatic cell count/100) [20].

The concentrations/activities of BA, LA, TAC, MDA, and IL- $1 \beta$ were determined in milk samples collected at weeks 2,4 , and 6 postpartum (days 14, 28, and 42 postpartum) and were used as indicators for the udder health status. The assays used for determining BA, LA, TAC, MDA, and IL- $1 \beta$ concentrations/activities in milk were similar to those used for blood plasma samples.

To determine the health status of the uterus, goats were subjected to transrectal ultrasonography (B-mode transrectal linear array probe, $5.0 \mathrm{MHz}$, Pie Medical Equipment B.V., Maastricht, Netherlands) 7, 20, and 40 at days postpartum as described by Hasem et al. [21] Briefly, the probe was fixed in a $1 \mathrm{~cm} \times 30 \mathrm{~cm}$ plastic rod to facilitate probe insertion into the rectal cavity; then, the probe was lubricated with a hydrosoluble gel and sheathed with a $2 \mathrm{~cm} \times 35 \mathrm{~cm}$ polyvinyl chloride pipe to avoid certain damage to the rectal mucosa. While the goat in the standing position, the probe was gently inserted (approximately $20 \mathrm{~cm}$ ) through the rectum until the anechoic content of the bladder was visible on the screen; then, the probe was rotated $90^{\circ}$ clockwise and $180^{\circ}$ counterclockwise across the reproductive tract until the uterine horns were scanned. Once a clear image for the uterus was obtained, the image was fixed, and the length and width of three uterine horn cross-sections were recorded. The diameter of the uterine horn was determined by calculating the mean of the diameters of the three uterine cross-sections. The intrauterine fluid volumes were evaluated and scored using a 4-point scale: 0 represented no fluid and 1-3 represented the increasing fluid volumes in the uterine horns as previously described by Mateus et al. [22].

\subsection{Colostrum Collection and Analyses}

Within $4 \mathrm{~h}$ postpartum, a representative colostrum sample was collected from each goat before allowing the newborn to reach dams udder. The colostrum composition (fat, 
protein, lactose, solids-not-fat, and salt) was immediately determined using a milk analyzer (Master Eco, Bulgaria). The values of total solids were estimated as a sum of the solidsnot-fat and salt values. The measuring range of milk analyzer for fat, protein, lactose, solids-not-fat, total solid and salts was $0.01-25 \% \pm 0.1 \%, 2-7 \% \pm 0.15 \%, 0.01-6 \% \pm 0.2 \%$, $3-15 \% \pm 0.15 \%, 0.4-4 \% \pm 0.05 \%$; respectively. The colostrum samples were stored at $-20{ }^{\circ} \mathrm{C}$ until analysis. The concentrations of colostrum immunoglobulin $\mathrm{G}(\mathrm{IgG})$ and $\mathrm{M}(\mathrm{IgM})$ were determined using kits obtained from Kamiya Biomedical Company (Seattle, WA, USA).

\subsection{Milk Collection and Analyses}

From week one to seven postpartum, the individual milk yield was determined by keeping the kids in separate pens for $20 \mathrm{~h}$ (from 2 p.m. to 10 a.m.) and milking the goats by hand until the udder was empty. The milk yield of each goat was recorded and multiplied with a correction factor of 1.2 to obtain daily milk yield [5]. Milk composition, including fat, protein, lactose, solids-not-fat, and salt, was determined in freshly collected milk using a milk analyzer (Master Eco, Bulgaria). The values of total solids were estimated as a sum of the solids-not-fat and salt values. The yield of energy-corrected milk (ECM) was calculated using the following equation: $\mathrm{ECM}(\mathrm{g} /$ day $)=$ milk yield $(\mathrm{g} /$ day $) \times / 0.749 \mathrm{Mcal} / \mathrm{kg}$ [23] The milk energy value (MEV, Mcal $/ \mathrm{kg})$ was calculated as follows: $\mathrm{MEV}=203.8+(8.36$ $\times \%$ of milk fat $)+(6.29 \times \%$ of milk crude protein $) / 1000$. The net energy required for lactation (NEL; Mcal $/ \mathrm{kg}$ ) was calculated using the following equation: NEL = milk yield $(\mathrm{kg}) \times[(0.0929 \times \%$ of milk fat $)+(0.0547 \times \%$ of milk crude protein $)+(0.0395 \times \%$ of milk lactose)] [24].

\subsection{Statistical Analyses}

All variables determined in this study, except colostrum variables, were analyzed using the MIXED procedure for repeated measurements of the Statistical Analysis System. The statistical model included the fixed effect of treatment (control, BsL, and BsH), time of sampling or time of data collection and their interactions. The random effect used in the model was individual goat. The generalized linear model (GLM) was used to determine the effect of treatment on the colostrum composition and the concentrations of colostrum IgG and IgM. Differences among treatment means were tested by the Duncan's new multiple range test. Results were shown as means \pm pooled SEM. Statistical significance was accepted at a probability value less than 0.05 .

\section{Results}

\subsection{Active Components of Bs Resin}

The GC-MS analysis of the extract identified 10 secondary metabolites (Table 1). The most abundant compounds identified in Bs were terpenoids, of which limonen-6-ol pivalate $(25.6 \%)$, cis- $(Z)-\alpha$-bisabolene epoxide $(23.5 \%)$, and $\beta$-amyrin $(15.7 \%$ monoterpenes) represented approximately $65 \%$ of the total identified compounds. Geranyl- $\alpha-$ terpinene, $\alpha$-amyrin, and cycloartanyl acetate were also identified in considerable amounts, accounting for $9.31 \%, 8.70 \%$, and $8.64 \%$ of the total identified compounds, respectively. Besides, vitamin A acid methyl ester, cembrene, $n$-octyl acetate, and androstan-17-one, 3-ethyl-3-hydroxy-5 alpha were identified, accounting for a sum of $8.43 \%$ of the total identified compounds. 
Table 1. Gas chromatographic-mass spectral analysis of the bioactive components of Boswellia sacra Flueck.

\begin{tabular}{|c|c|c|c|c|c|}
\hline Component & Chemical Class & $\begin{array}{l}\text { Retention Time } \\
\text { (min) }\end{array}$ & $\begin{array}{l}\text { Molecular } \\
\text { Formula }\end{array}$ & $\begin{array}{c}\text { Molecular } \\
\text { Weight (g/mol) }\end{array}$ & $\begin{array}{l}\text { Proportion of } \\
\text { Total Area (\%) }\end{array}$ \\
\hline Limonen-6-ol, pivalate & $\begin{array}{l}\text { Cyclic } \\
\text { monoterpene }\end{array}$ & 26.34 & $\mathrm{C}_{15} \mathrm{H}_{24} \mathrm{O}_{2}$ & 236.3 & 25.6 \\
\hline cis- $(Z)-\alpha$-Bisabolene epoxide & Sesquiterpenes & 25.99 & $\mathrm{C}_{15} \mathrm{H}_{24} \mathrm{O}$ & 220.3 & 23.5 \\
\hline$\beta$-Amyrin & Triterpenoid & 41.26 & $\mathrm{C}_{30} \mathrm{H}_{50} \mathrm{O}$ & 426.7 & 15.7 \\
\hline Geranyl- $\alpha$-terpinene & Terpenoids & 23.293 & $\mathrm{C}_{20} \mathrm{H}_{32}$ & 136.2 & 9.31 \\
\hline$\alpha$-Amyrin & Triterpenoid & 40.13 & $\mathrm{C}_{30} \mathrm{H}_{50} \mathrm{O}$ & 426.7 & 8.70 \\
\hline Cycloartanyl acetate & Triterpenoid/sterol & 48.22 & $\mathrm{C}_{32} \mathrm{H}_{54} \mathrm{O}_{2}$ & 470.8 & 8.64 \\
\hline Vitamin A acid methyl ester & - & 39.74 & $\mathrm{C}_{21} \mathrm{H}_{30} \mathrm{O}_{2}$ & 314.4 & 3.27 \\
\hline Cembrene & Diterpenoids & 25.99 & $\mathrm{C}_{20} \mathrm{H}_{32}$ & 272.4 & 2.40 \\
\hline$n$-Octyl acetate & Fatty alcohol esters & 8.407 & $\mathrm{C}_{10} \mathrm{H}_{20} \mathrm{O}_{2}$ & 172.2 & 1.44 \\
\hline $\begin{array}{l}\text { Androstan-17-one, } \\
\text { 3-ethyl-3-hydroxy-5 alpha }\end{array}$ & Sterol & 22.10 & $\mathrm{C}_{21} \mathrm{H}_{34} \mathrm{O}_{2}$ & 318.5 & 1.32 \\
\hline
\end{tabular}

\subsection{Effects of Treatment on Hematological and Immunological Variables}

Hematological and immunological variables in transitioning goats that received 0 (nBS), 2 (BsL), and $4(\mathrm{BsH}) \mathrm{g}$ of Bs resin daily from week 2 prepartum to week 7 postpartum are shown in Table 2. None of the treatments affected the hematological variables, including RBC count, $\mathrm{WBC}$ count and type, and $\mathrm{Hb}$ concentrations. However, both the BsL and BsH treatments improved PA $(p=0.057)$ and PI $(p=0.036)$ of phagocytes and blood plasma BA $(p=0.047)$ compared with the nBS treatment. Both the Bs treatments decreased the LA ( $p=0.047)$ and concentration of blood plasma IL-1 $\beta(p=0.013)$ compared with the nBS treatment. Regardless of the treatment, the percentage of monocytes showed significant increases at the first stages of lactation, weeks 1 and 3 postpartum, while it decreased with lactation advancement (weeks 5 and 7 postpartum) (Figure 1). Treatment by time interaction analysis showed that both levels of Bs significantly decreased the percentages of BA and LA at week 3 postpartum, while significantly increased blood plasma PA at week 5 postpartum (Figure 1).

Table 2. Hematological and immunological variables for transitioning goats that received 0 (nBS), 2 (BsL), and 4 (BsH) g of Boswellia sacra resin daily from week 2 prepartum to week 7 postpartum.

\begin{tabular}{|c|c|c|c|c|c|c|c|}
\hline \multirow{2}{*}{ Item } & \multicolumn{3}{|c|}{ Treatment (T) } & \multirow{2}{*}{ SEM } & \multicolumn{3}{|c|}{$p$-Value } \\
\hline & nBS & BsL & BsH & & $\mathbf{T}$ & Time (Ti) & $\mathbf{T} \times \mathbf{T i}$ \\
\hline \multicolumn{8}{|c|}{ Hematological variables } \\
\hline $\operatorname{RBC}\left(10^{6} / \mathrm{mm}^{3}\right)$ & 20.70 & 20.25 & 20.80 & 0.5752 & 0.773 & $<0.001$ & 0.803 \\
\hline $\mathrm{Hb}(\mathrm{g} / \mathrm{dL})$ & 12.25 & 12.21 & 12.30 & 0.226 & 0.961 & $<0.001$ & 0.651 \\
\hline Ht $(\%)$ & 37.40 & 36.90 & 37.40 & 0.720 & 0.852 & $<0.001$ & 0.738 \\
\hline \multicolumn{8}{|c|}{ Immunological variables } \\
\hline $\mathrm{WBC}\left(10^{3} / \mathrm{mm}^{3}\right)$ & 25.10 & 24.80 & 25.05 & 0.363 & 0.823 & 0.015 & 0.950 \\
\hline Lymphocytes (\%) & 41.25 & 41.40 & 41.30 & 0.453 & 0.972 & $<0.001$ & 0.469 \\
\hline Neutrophils (\%) & 26.80 & 26.50 & 26.250 & 0.729 & 0.866 & $<0.001$ & 0.166 \\
\hline Eosinophils (\%) & 13.50 & 13.50 & 14.00 & 0.435 & 0.648 & 0.027 & 0.910 \\
\hline Basophils (\%) & 0.80 & 0.80 & 0.75 & 0.094 & 0.909 & 0.065 & 0.906 \\
\hline Monocytes (\%) & 17.65 & 17.90 & 17.60 & 0.295 & 0.7451 & $<0.001$ & 0.036 \\
\hline PA $(\%)$ & 19.81 & 20.54 & 20.91 & 0.258 & 0.057 & 0.678 & 0.029 \\
\hline PI & $2.01^{b}$ & $2.88^{a}$ & $2.96^{\mathrm{a}}$ & 0.377 & 0.036 & $<0.001$ & 0.087 \\
\hline BA (S.I.) & 42.94 & 41.81 & 41.74 & 0.300 & 0.089 & $<0.001$ & 0.022 \\
\hline LA $($ Unit $/ \mathrm{mL})$ & $13.90^{b}$ & $13.75^{a b}$ & $13.21^{\mathrm{a}}$ & 0.258 & 0.047 & 0.678 & 0.029 \\
\hline Interleukin-1 $\beta(\mathrm{pg} / \mathrm{mL})$ & $11.95^{\mathrm{a}}$ & $11.05^{b}$ & $10.98^{b}$ & 0.244 & 0.013 & $<0.001$ & 0.135 \\
\hline
\end{tabular}

Mean values in a row bearing different superscripts $(\mathrm{a}, \mathrm{b})$ differ significantly $(p<0.05)$. RBC, red blood cell; Hb, hemoglobin; Ht, hematocrit; WBC, white blood cell; PA, phagocytic activity (percentage of phagocytic cells containing bacterial cells); PI, phagocytic index (number of engulfed bacterial cells per phagocytic cell); BA, bactericidal activity; LA, lysozyme activity. 

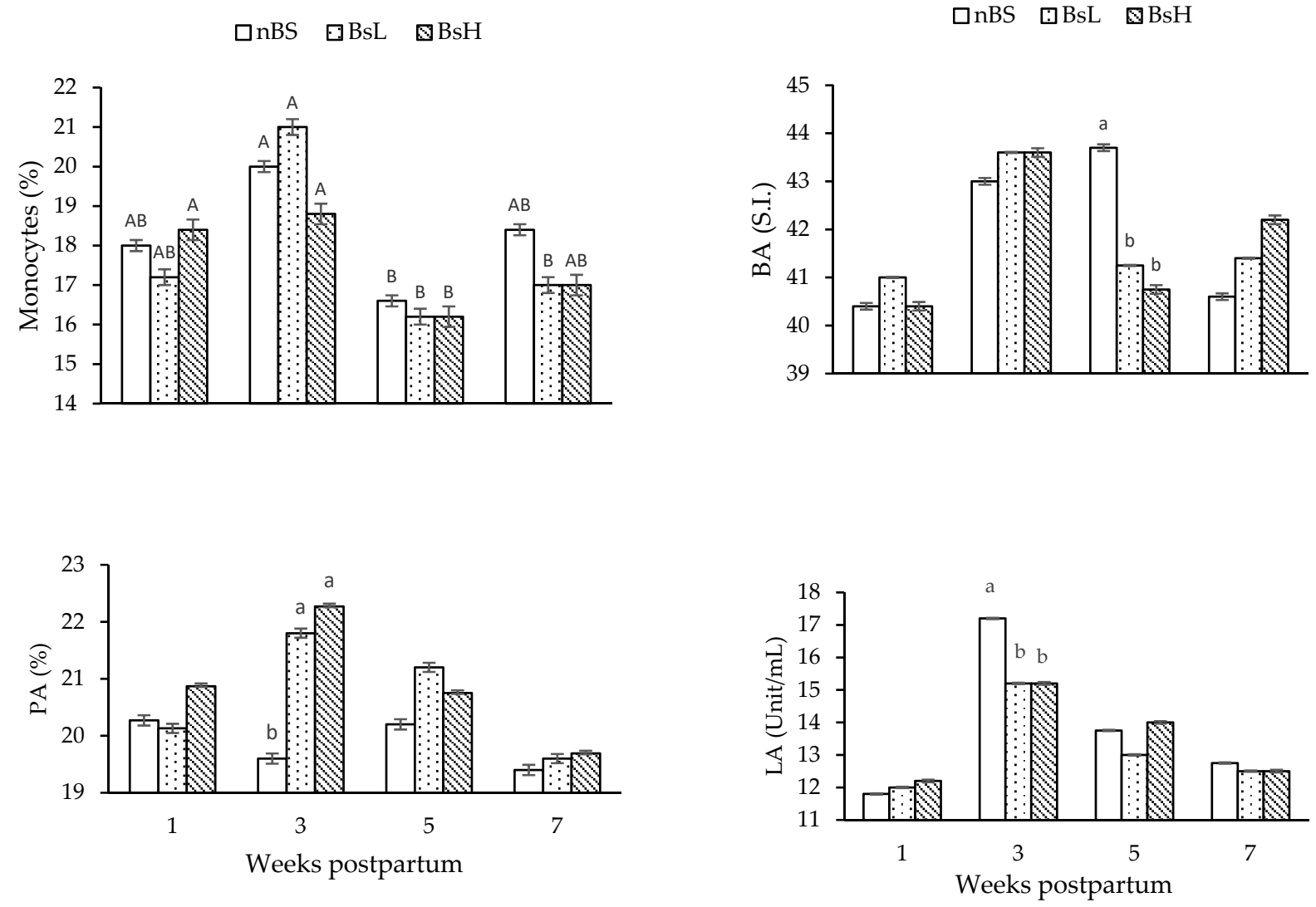

Figure 1. Treatment by time interaction (means \pm SEM) effects on the percentage of monocytes, bactericidal activity (BA), phagocytic activity (PA), and lysozyme activity (LA) of transitioning goats that received 0 (nBS), 2 (BsL), and 4 (BsH) g of Boswellia sacra resin daily from week 2 prepartum to week 7 postpartum. Means within the same time period having different superscripts $(a, b)$ differ significantly $(p<0.05)$ and means within the same treatment having different superscripts (A, B) differ significantly $(p<0.05)$.

\subsection{Effects of Treatment on Blood Metabolites}

The blood plasma metabolites for transitioning goats that received 0 (nBS), 2 (BsL), and $4(\mathrm{BsH}) \mathrm{g}$ of Bs resin daily from week 2 prepartum to week 7 postpartum are shown in Table 3. Treatment with both levels of Bs did not affect the blood plasma concentrations of total protein, albumin, and cholesterol. Both levels of Bs significantly decreased the concentrations of blood plasma glucose $(p<0.001)$, urea $(p=0.030)$, NEFAs $(p<0.001)$, and hydroxybutyric acid $(p=0.015)$, whereas they significantly increased TAC $(p<0.001)$ compared with the nBS treatment. The BsH treatment tended to decrease the concentration of plasma MDA compared with other treatments $(p=0.091)$.

Treatment by time interaction analysis revealed that treatment with both levels of Bs significantly improved blood plasma albumin compared with control throughout the experimental period except at week 3 postpartum (Figure 2). Compared with nBS, the HBs treatment significantly decreased the blood plasma NEFAs concentrations from week 3 postpartum to week 7 postpartum; however, this effect was observed at weeks 5 and 7 postpartum in the LBs treatment. Bothe levels of Bs significantly decreased the concentrations of blood plasma BHB from week 3 postpartum to week 5 postpartum compared with control (Figure 2). Compared with control, both levels of Bs improved blood plasma TAC concentrations throughout the experimental period; however, this effect was significant at weeks 3 and 5 postpartum (Figure 2). 
Table 3. Blood plasma metabolites for transitioning goats that received 0 (nBs), 2 (BsL), and 4 (BsH) g of Boswellia sacra resin daily from week 2 prepartum to week 7 postpartum.

\begin{tabular}{|c|c|c|c|c|c|c|c|}
\hline \multirow{2}{*}{ Item } & \multicolumn{3}{|c|}{ Treatment (T) } & \multirow{2}{*}{ SEM } & \multicolumn{3}{|c|}{$p$-Value } \\
\hline & nBS & BsL & BsH & & $\mathbf{T}$ & Time (Ti) & $\mathbf{T} \times \mathbf{T i}$ \\
\hline Total protein (g/dL) & 6.41 & 6.28 & 6.24 & 0.061 & 0.117 & 0.820 & 0.847 \\
\hline Albumin (g/dL) & 3.41 & 3.41 & 3.49 & 0.040 & 0.280 & 0.095 & $<0.001$ \\
\hline Glucose (mg/dL) & $84.08^{\mathrm{a}}$ & $83.83^{b}$ & $81.70^{\mathrm{c}}$ & 0.483 & $<0.001$ & 0.276 & 0.076 \\
\hline Cholesterol (mg/dL) & 210.00 & 210.92 & 210.50 & 1.782 & 0.937 & 0.999 & 0.293 \\
\hline Urea $(\mathrm{mg} / \mathrm{dL})$ & $14.95^{\mathrm{a}}$ & $13.64^{\mathrm{ab}}$ & $13.30^{b}$ & 0.513 & 0.030 & 0.5063 & 0.059 \\
\hline NEFAs (mmol/L) & $0.564^{\mathrm{a}}$ & $0.528^{b}$ & $0.519^{b}$ & 0.769 & $<0.001$ & 0.1567 & 0.028 \\
\hline $\mathrm{BHB}(\mathrm{mmol} / \mathrm{L})$ & $0.323^{a}$ & $0.307^{b}$ & $0.301^{b}$ & 0.005 & 0.015 & $<0.001$ & $<0.001$ \\
\hline $\mathrm{TAC}(\mu \mathrm{mol} / \mathrm{L})$ & $418.46^{b}$ & $420.85^{a}$ & $421.50^{a}$ & 0.646 & 0.044 & $<0.001$ & 0.024 \\
\hline MDA (Umol/L) & 14.15 & 14.05 & 13.44 & 0.281 & 0.091 & $<0.001$ & 0.483 \\
\hline
\end{tabular}

Mean values in a row bearing different superscripts $(a, b)$ differ significantly $(p<0.05)$. NEFAs, non-esterified fatty acids; BHB, $\beta$ hydroxybutyrate; TAC, total antioxidant capacity; MDA, malondialdehyde.
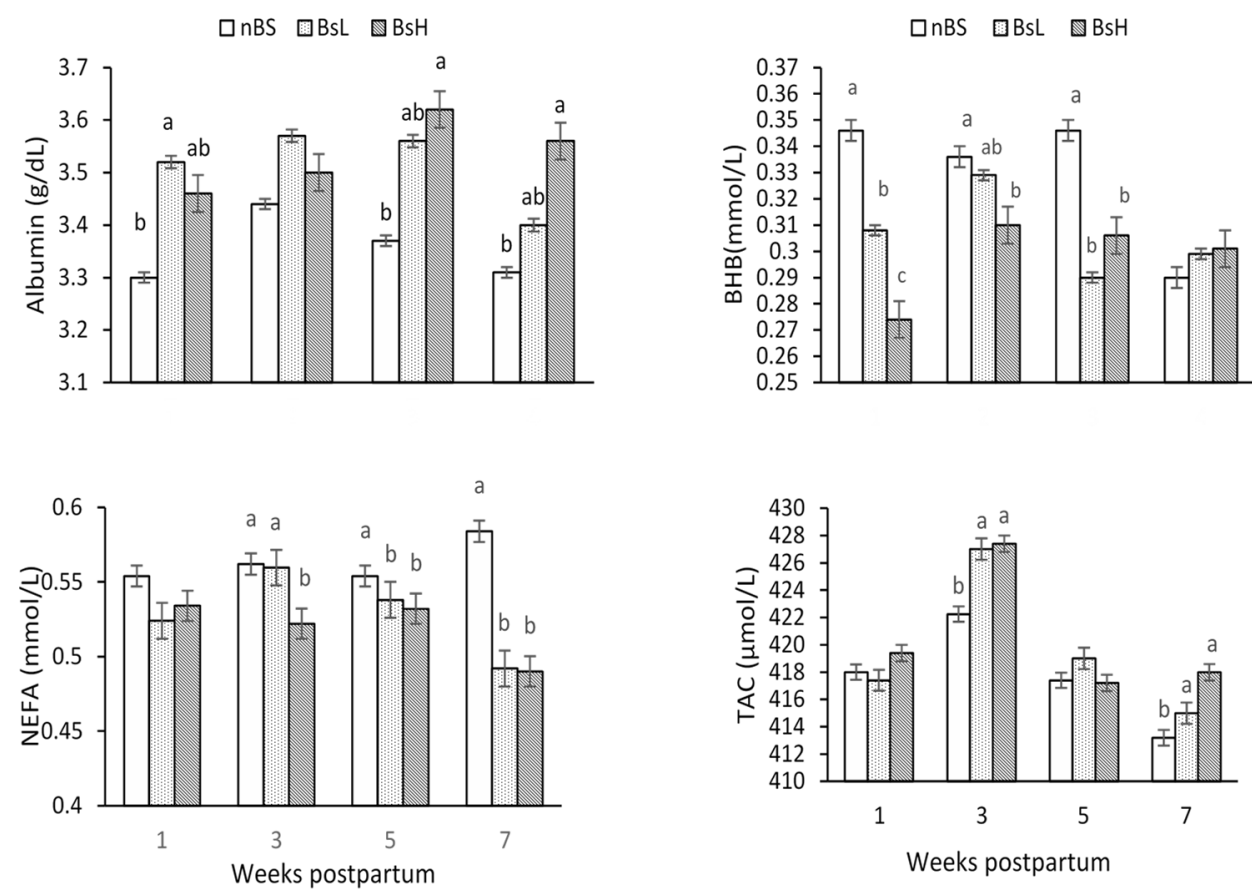

Figure 2. Treatment by time interaction (means \pm SEM) effects on blood plasma albumin concentrations, $\beta$-hydroxybutyrate (BHB), non-esterified fatty acids (NEFAs), and total antioxidant capacity (TAC) of transitioning goats that received 0 (nBS), 2 (BsL), and 4 (BsH) g of Boswellia sacra resin daily from week 2 prepartum to week 7 postpartum. Means within the same time period having different superscripts $(\mathrm{a}, \mathrm{b}, \mathrm{c})$ differ significantly $(p<0.05)$.

\subsection{Effects of Treatment on Udder and Uterus Health Bioindicators}

The uterus and udder health indicators for transitioning goats that received 0 (nBS), 2 (BsL), and $4(\mathrm{BsH}) \mathrm{g}$ of Bs resin daily from week 2 prepartum to week 7 postpartum are shown in Table 4 . Both levels of Bs significantly decreased the uterine horn diameter $(p<0.001)$ and tended to decrease the intrauterine fluid score $(p=0.064)$, indicating improved uterine involution compared with the nBS treatment. Treatment by time interaction analysis showed that both levels of Bs significantly decreased the intrauterine fluid score early on day 7 postpartum, and this effect continued until day 40 postpartum (Figure 3). 
Table 4. Uterus and udder health indicators for transitioning goats that received 0 (nBS), 2 (BsL), and 4 (BsH) Boswellia sacra resin daily from week 2 prepartum to week 7 postpartum.

\begin{tabular}{|c|c|c|c|c|c|c|c|}
\hline \multirow{2}{*}{ Item } & \multicolumn{3}{|c|}{ Treatment $(\mathrm{T})$} & \multirow{2}{*}{ SEM } & \multicolumn{3}{|c|}{$p$-Value } \\
\hline & nBs & BsL & BsH & & $\mathbf{T}$ & Time (Ti) & $\mathbf{T} \times \mathbf{T i}$ \\
\hline \multicolumn{8}{|c|}{ Uterus health indicators } \\
\hline Uterine horn diameter $(\mathrm{cm})$ & $3.68^{\mathrm{a}}$ & $3.198^{b}$ & $2.89^{\mathrm{c}}$ & 0.106 & $<0.001$ & $<0.001$ & 0.147 \\
\hline Intrauterine fluid score & 1.92 & 1.24 & 1.35 & 0.256 & 0.064 & $<0.001$ & 0.006 \\
\hline \multicolumn{8}{|c|}{ Udder health indicators } \\
\hline $\begin{array}{l}\text { Linear somatic cell count score } \\
\qquad\left(\times 10^{3} \text { cell } / \mathrm{mL}\right)\end{array}$ & $4.044^{\mathrm{a}}$ & $2.894^{b}$ & $2.876^{b}$ & 0.272 & 0.004 & 0.002 & 0.308 \\
\hline $\mathrm{BA}(\mathrm{SI})$ & $47.33^{\mathrm{a}}$ & $45.87^{b}$ & $45.27^{\mathrm{b}}$ & 0.865 & 0.009 & 0.392 & 0.080 \\
\hline LA (unit/mL) & 20.07 & 20.137 & 20.20 & 0.255 & 0.934 & $<0.001$ & 0.052 \\
\hline $\mathrm{TAC}(\mu \mathrm{mol} / \mathrm{L})$ & $427.40^{b}$ & $428.73^{a b}$ & $430.40^{\mathrm{a}}$ & 0.648 & 0.012 & $<0.001$ & 0.334 \\
\hline Interleukin-1 $\beta$ & $15.30^{\mathrm{a}}$ & $13.96^{\mathrm{b}}$ & $14.90^{\mathrm{ab}}$ & 0.404 & 0.029 & $<0.001$ & 0.609 \\
\hline
\end{tabular}

Mean values in a row bearing different superscripts $(a, b, c)$ differ significantly $(p<0.05)$. BA, bactericidal activity; LA, lysosomal activity; TAC, antioxidant capacity.

\section{口nBS $⿴$ BsL $\mathbb{B}$ BsH}

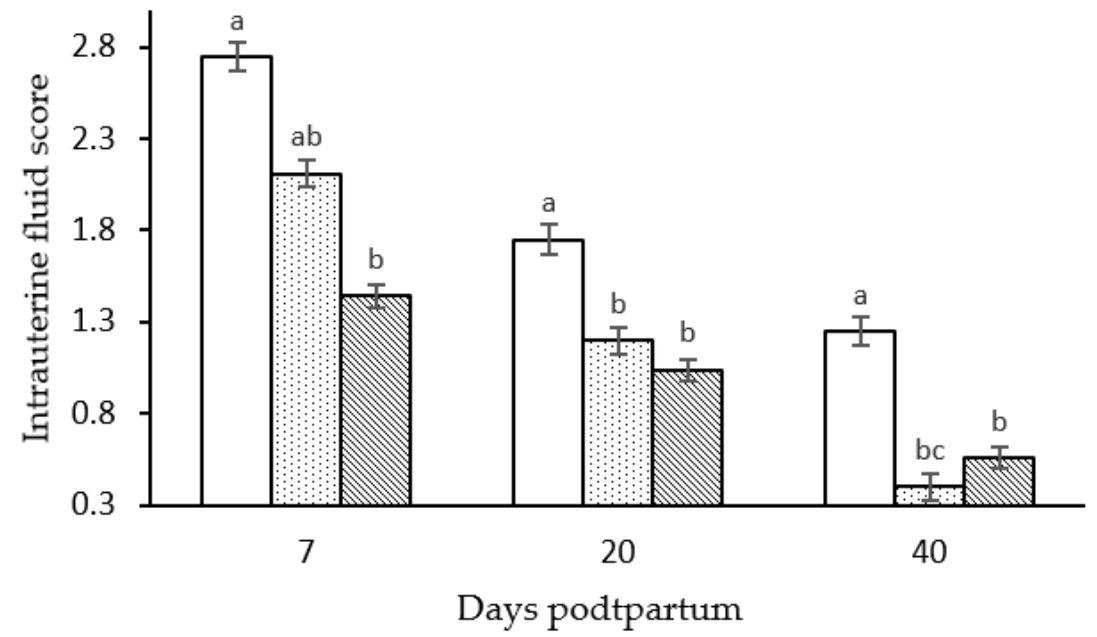

Figure 3. Treatment by time interaction (means \pm SEM) effects on intrauterine fluid score of transitioning goats that received 0 (nBS), 2 (BsL), and 4 (BsH) g of Boswellia sacra resin daily from week 2 prepartum to week 7 postpartum. Means within the same time period having different superscripts $(\mathrm{a}, \mathrm{b}, \mathrm{c})$ differ significantly $(p<0.05)$.

Compared with the nBS treatment, both levels of Bs significantly decreased milk somatic cell count $(p<0.004)$, which was associated with a significant improvement in milk BA (low bacterial SI). The BsH treatment significantly increased milk TAC compared with the nBS treatment $(p<0.001)$, whereas the BsL treatment showed an intermediate value. The lowest milk IL-1 $\beta$ content was observed in the BsL treatment $(p=0.029)$, followed by the $\mathrm{BsH}$ and nBS treatments.

\subsection{Effects of Treatment on Colostrum Components and Immunoglobulin Concentrations}

Colostrum composition and immunoglobulin levels for transitioning goats that received 0 (nBS), 2 (BsL), and 4 (BsH) g of Bs resin daily from week 2 prepartum to week 7 postpartum are shown in Table 5. Compared with the nBS treatment, the BsH treatment significantly increased the percentages of colostrum fat, protein, and lactose and, thus, the percentage of colostrum total solids, whereas the BsL treatment significantly increased the percentages of colostrum protein and lactose, which resulted in an intermediate increase 
in the percentage of colostrum total solids. The BsL treatment significantly increased the concentration of colostrum IgM but did not affect the concentration of colostrum IgG compared with the nBS and BsH treatments.

Table 5. Feed intake, body weights, colostrum composition and immunoglobulin contents, milk yield and composition, and energy indicators for transitioning goats that received 0 (nBS), 2 (BsL), and $4(\mathrm{BsH}) \mathrm{g}$ of Boswellia sacra resin daily from week 2 prepartum to week 7 postpartum.

\begin{tabular}{|c|c|c|c|c|c|c|c|}
\hline \multirow{2}{*}{ Item } & \multicolumn{3}{|c|}{ Treatment (T) } & \multirow{2}{*}{ SEM } & \multicolumn{3}{|c|}{$p$-Value } \\
\hline & nBS & BsL & BsH & & $\mathbf{T}$ & Time (Ti) & $\mathbf{T} \times \mathbf{T i}$ \\
\hline Daily feed intake (g DM/goat) & 801.05 & 799.82 & 795.03 & 15.74 & 0.517 & 0.147 & 0.287 \\
\hline Body weight one week postpartum (kg) & 25.59 & 26.24 & 26.56 & 1.24 & 0.841 & - & - \\
\hline Body weight seven weeks postpartum (kg) & 23.72 & 24.51 & 23.80 & 2.47 & 0.637 & - & - \\
\hline \multicolumn{8}{|c|}{ Colostrum composition $(\%)$} \\
\hline Fat & $6.41^{b}$ & $6.72^{b}$ & $8.82^{\mathrm{a}}$ & 0.349 & 0.041 & - & - \\
\hline Protein & $4.83^{\mathrm{b}}$ & $5.24^{\mathrm{a}}$ & $5.26^{\mathrm{a}}$ & 0.390 & 0.046 & - & - \\
\hline Lactose & $5.78^{b}$ & $8.36^{\mathrm{a}}$ & $7.75^{\mathrm{a}}$ & 0.421 & 0.008 & - & - \\
\hline Solids-not-fat & $11.52^{b}$ & $14.15^{\mathrm{a}}$ & $14.42^{\mathrm{a}}$ & 0.632 & 0.043 & - & - \\
\hline Total solids & $17.93^{b}$ & $20.87^{a b}$ & $23.24^{\mathrm{a}}$ & 0.977 & 0.021 & - & - \\
\hline \multicolumn{8}{|c|}{ Colostrum immunoglobulin contents(mg/dL) } \\
\hline $\operatorname{IgG}$ & 270.60 & 273.61 & 276.40 & 6.40 & 0.386 & - & - \\
\hline $\operatorname{Ig} M$ & $987.40^{\mathrm{b}}$ & $993.20^{a}$ & $986.80^{b}$ & 3.60 & $<0.001$ & - & - \\
\hline \multicolumn{8}{|c|}{ Milk yield and composition } \\
\hline Milk yield (kg/day) & $1.278^{\mathrm{b}}$ & $1.480^{\mathrm{a}}$ & $1.569^{\mathrm{a}}$ & 0.077 & 0.020 & $<0.001$ & $<0.001$ \\
\hline $\mathrm{ECM}(\mathrm{kg} /$ day $)$ & $1.187^{\mathrm{b}}$ & $1.351^{\mathrm{a}}$ & $1.389^{\mathrm{a}}$ & 0.069 & 0.031 & $<0.001$ & $<0.001$ \\
\hline \multicolumn{8}{|c|}{ Milk composition $(\%)$} \\
\hline Fat & 3.57 & 3.54 & 3.36 & 0.359 & 0.894 & $<0.001$ & 0.083 \\
\hline Protein & 3.04 & 3.00 & 3.07 & 0.046 & 0.463 & $<0.001$ & 0.937 \\
\hline Lactose & 4.02 & 4.49 & 4.64 & 0.058 & 0.061 & $<0.001$ & 0.632 \\
\hline Solids-not-fat & 7.03 & 7.42 & 7.622 & 0.099 & 0.201 & $<0.001$ & 0.517 \\
\hline Total solids & 11.29 & 11.66 & 11.72 & 0.909 & 0.407 & $<0.001$ & 0.140 \\
\hline \multicolumn{8}{|c|}{ Energy status indicators } \\
\hline Fat-protein ratio & 1.17 & 1.18 & 1.09 & 0.116 & 0.802 & $<0.001$ & 0.106 \\
\hline MEV (Mcal/kg) & 0.253 & 0.252 & 0.251 & 0.003 & 0.925 & $<0.001$ & 0.089 \\
\hline NEL (Mcal/kg) & $0.861^{\mathrm{b}}$ & $1.01^{\mathrm{a}}$ & $1.03^{\mathrm{a}}$ & 0.056 & 0.041 & $<0.001$ & $<0.001$ \\
\hline
\end{tabular}

Mean values in a row bearing different superscripts $(a, b)$ differ significantly $(p<0.05)$. IgG, immunoglobulin $\mathrm{G}$; IgM, immunoglobulin $\mathrm{M}$; ECM, energy-corrected milk; MEV, milk energy value; NEL, net energy for lactation.

\subsection{Effects of Treatment on Milk Yield and Components and Energy Status Implications}

Daily milk yield, milk composition, and energy status indicators for transitioning goats that received $0(\mathrm{nBS}), 2(\mathrm{BsL})$, and $4(\mathrm{BsH}) \mathrm{g}$ of Bs resin daily from week 2 prepartum to week 7 postpartum are shown in Table 5 . Both levels of Bs increased the daily milk yield and ECM $(p<0.001)$ and tended to increase milk lactose content $(p=0.061)$ compared with the nBS treatment. Both levels of Bs increased NEL $(p=0.041)$ compared with the nBS treatment. As shown by the treatment by time interaction analysis, the increases in the individual milk yield, energy corrected milk, and net energy for lactation due to Bs treatments were observed from week 2 postpartum to week 5 postpartum (Figure 4). 

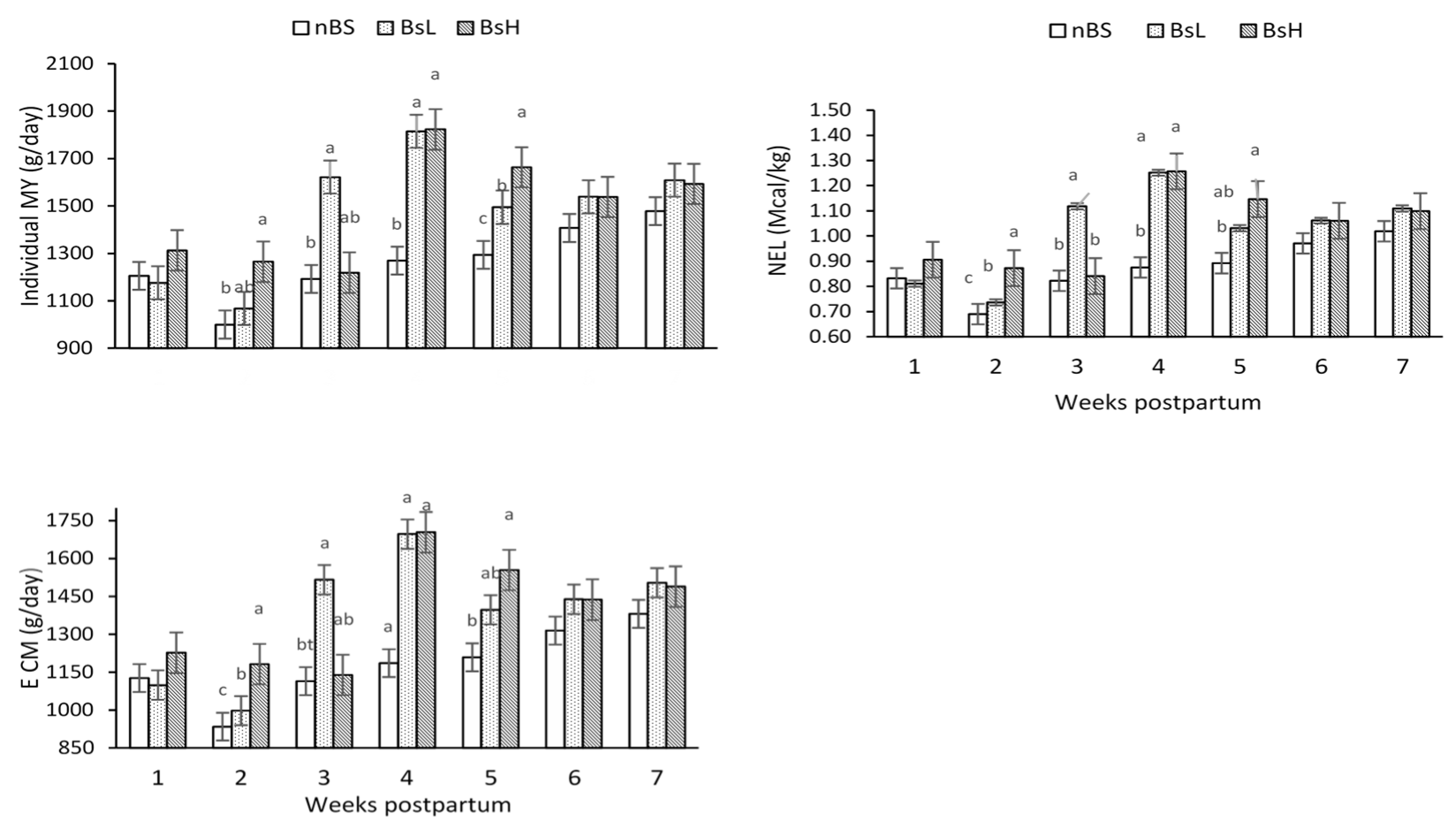

Figure 4. Treatment by time interaction (means \pm SEM) effects on individual milk yield (MY), net energy for lactation (NEL), and energy corrected milk yield (ECM) of transitioning goats that received 0 (nBS), 2 (BsL), and 4 (BsH) g of Boswellia sacra resin daily from week 2 prepartum to week 7 postpartum. Means within the same time period having different superscripts $(\mathrm{a}, \mathrm{b}, \mathrm{c})$ differ significantly $(p<0.05)$.

\section{Discussion}

The pharmacological properties of the secondary metabolites of Bs species have been highlighted in numerous studies [8,25-27]. Nevertheless, few studies have shown its effects on the health and metabolic status of transitioning dairy ruminants. This study was conducted to evaluate the potential benefits of Bs gum resin, aiming its biological active secondary metabolites, on the health of transitioning dairy goats by assessing immune response indicators, udder and uterus health indicators, metabolic indicators, and colostrum and milk production efficiency. It is believed that the transition period is one of the most challenging reproductive windows that are associated with the occurrence of severe metabolic changes, hormonal imbalances, and inflammatory responses [4]. These changes can negatively affect both the health and performance of animals, specifically uterine involution and milk production (the two main physiological events related to the transition period) $[5,28]$.

In this study, the GC-MS performed on the Bs extract revealed the occurrence of essential secondary metabolites that can modulate and improve both the health and productivity of transitioning dairy ruminants. Limonene and cis- $(Z)-\alpha$-bisabolene epoxide were the major secondary metabolites identified in the Bs extract. These secondary metabolites have strong biological anti-inflammatory and antioxidant activities [29]. Moreover, secondary metabolites with antibacterial/antifungal (limonene and $\alpha$ - and $\beta$-amyrin [30] and $n$-octyl acetate [31]) antihyperglycemic and hypolipidemic ( $\alpha, \beta$-amyrin [28]) activities, and a steroid-like effect (androstan-17-one, 3-ethyl-3-hydroxy-5 alpha [32]) were detected. The active components of Bs can exert their systematic effects in ruminants by affecting the activity of rumen microorganisms and subsequent fermentation outputs and/or by reaching blood circulation after absorption to modulate several biological and metabolic processes, mainly those related to glucose homeostasis, inflammation, and immunity [33].

During the transition period, the immune system of dairy animals plays a crucial role in maintaining animal health and minimizing the opportunity of pathogens to cause 
infections, particularly those related to postpartum diseases (endometritis and mastitis). In this respect, the innate immunity is the first line of defense against infectious agents. The innate immune system includes phagocytic cells, soluble factors, and physical barriers [16]. In this study, treatment with Bs improved the functionality of phagocytic cells by increasing their phagocytic potentials. This improvement in phagocytic activity may explain the decreased BA and LA of Bs-treated goats, as the improved engulfing potential of phagocytes may decrease the microbial load and thus the need for other immune system defense actions. The immunomodulatory role of Bs has been confirmed in several studies; Bs can modulate both the innate immunity (phagocytosis of macrophage activity) and humoral immunity (antibody production) in a dose-dependent manner, as high Bs levels have adverse effects on immune system functions, whereas moderate and low doses show positive effects [25]. These findings together support the suitability of the Bs doses used in this study.

In transitioning dairy animals, rather than pathogenic diseases, clinical and/or subclinical inflammatory states can be evoked in the postpartum period as a response to the endometrial damage during parturition [7] and/or the occurrence of metabolic diseases [4]. The increase in the inflammatory mediators, leukotrienes, can delay the occurrence of uterine involution and induce several metabolic disorders and insulin resistance that negatively impact the health and productivity of dairy animals [7]. Leukotrienes are small mediator chemicals produced by cells in the body, which can cause inflammation by promoting free radical damages, cell adhesion, autoimmune responses, and migration of the inflammatory-producing cells to the inflamed area [10].

In this study, the goats treated with both levels of Bs had lower IL- $1 \beta$ concentrations in blood plasma and milk. This could be attributed to the anti-inflammatory effects of limonene, cis-(Z)- $\alpha$-bisabolene epoxide (bisabolene; [29]), and amyrins (the precursors of boswellic acid, which are the major anti-inflammatory compounds in Bs) [34]. Boswellic acid and other pentacyclic triterpenes have a chemical structure similar to that of steroids and an anti-inflammatory activity [35]. A major target of boswellic acid are the immune cells as they have been shown to decrease the production of proinflammatory cytokines including IL-1, IL-2, IL-6, interferon- $\gamma$, and tumor necrosis factor- $\alpha$, which have a certain distractive action on several tissues, such as insulin-producing cells and intestinal tissues [9]. Furthermore, instead of the action of the Bs active components on the immune system, the decrease in IL-1 $\beta$ concentrations observed in this study could be ascribed to the improved PA of phagocytic cells and may contribute to the elimination of cytokine synthesis as a result of the low microbial load.

Usually, transitioning dairy animals show homeorhetic responsesdefined as NEB, which is characterized by increased body fat lipolysis due to the lack of glucose as an energy source and increase in undesirable metabolites, such as NEFAs and $\beta$-hydroxybutyrate (BHB). Goats treated with Bs showed better metabolic homeostasis than control goats, as indicated by lower concentrations of NEFAs and BHB with no decrease in their body weights. Ahangarpour et al. [36] have found that Bs resin consumption increased the insulin level and decreased the insulin resistance index in rats with type 2 diabetes mellitus. This effect is crucially required by transitioning dairy animals to improve cellular glucose uptake as a homeorhetic mechanism to high energy demand of lactation and due to tissue insulin resistance. Moreover, the intense elevation in NEB can depress the immune system, due to impaired leukocyte functions, favoring changes in the metabolic profile, which can impair the health of the animals and increase the risk of developing metabolic diseases, such as lipomobilization, ketosis, and hypocalcemia [4].

Overall, during the transition period, interactions between metabolic status, immune system function, and inflammatory status determine the productive and reproductive performances of animals during the subsequent productive cycle [6]. These interactions could be easily detected in this study; enhancements in immune system function, inflammatory status, and metabolism due to Bs supplementation were associated with significant improvements in the uterine and udder health, colostrum chemical composition, immunoglobulin profile, and milk yield and composition up to week 5 of lactation. The 
activation of immune function has a huge metabolic cost. During the postpartum period, inflammation, coupled with the increased cellular metabolism, upregulates immune gene expression, and mitochondrial uncoupling further increases energy requirements. Inflammation reprioritizes nutrients (glucose) in favor of the immune system at the expense of the mammary gland requirements and thus milk production and other pivotal physiological events postpartum, such as those related to reproduction $[6,7]$.

Regarding uterine health, uterine involution is an important physiological process that takes place after parturition up to 45 days postpartum. During this period, three overlapping processes, namely, uterine contraction, loss of tissue, and tissue repair, should adequately occur to restore the ability of the uterus to receive a new conceptus [37]. Thus, the antimicrobial, anti-inflammatory, and tissue regeneration and remodeling potentials of some active components in Bs can accelerate and improve uterine involution in transitioning dairy animals. Among these secondary metabolites, boswellic acids, $\alpha$ - and $\beta$-amyrin, and bisabolene were the most active molecules $[27,30]$. It is also worth noting that the improvements in uterine involution of Bs-treated goats may be indirectly related to the decreased concentrations of NEFAs, which has been correlated with the incidence of many postpartum uterine diseases. For example, prepartum cows with NEFAs values of more than $0.3 \mathrm{mmol} / \mathrm{L}$ were 1.8 times more likely to develop metritis [38]. The positive effects of Bs on uterine involution has been confirmed in this study as goats treated with Bs had lower uterine horn thickness and intrauterine fluid content than control goats. Hormonally, both oxytocin and prostaglandin $\mathrm{F}_{2 \alpha}\left(\mathrm{PGF}_{2 \alpha}\right)$ are the main hormones that contribute to myometrium contraction, leading to a certain reduction in uterine size [37]. The hormonal profiles of the goats were not examined in this study. However, the present data refer to the importance of studying the relationship between Bs administration and the hormonal profiles of transitioning animals; particularly, Bs is rich in steroid-like components that can affect hormonal balance of animals during the transition period.

Treatment with Bs also improved udder health and, subsequently, colostrum and milk production. The milk of Bs-treated goats contained lower somatic cell counts than that of control goats. The low number of somatic cells was associated with higher milk BA and LA and higher TAC. Furthermore, increased concentrations of colostrum antibodies, mainly IgM, were observed in BsL-treated goats. These findings together support the positive effects of the active components of Bs on udder health, specifically immune system functioning and the antioxidant activity of mammary gland cells. For instance, bisabolene has anti-inflammatory and selective anticarcinogenic effects against mammary gland tumors [39]. The improved milk production of Bs-treated goats could be also attributed to the effects of steroid-like compounds, such as androstan-17-one, 3-ethyl-3-hydroxy-5 alpha, and cycloartanyl acetate (plant steroids), which were identified in the Bs resin used in this study. Sterol compounds contribute to increasing milk production in a hormonal manner by stimulating the steroidogenesis process and growth hormone synthesis, in addition to their anabolic effects [40]. In this context, Suprayogi [41] has reported that ewes fed diets containing Sauropusandrogynus (L.) Merr had increased milk production due to the presence of androstan-17-one, 3-ethyl-3-hydroxy 5 alpha in this plant, which serves as a precursor for steroid hormones (progesterone, estradiol, testosterone, and glucocorticoids) required for alveolar/ductal mammary gland development and lactogenesis. Furthermore, in our study, supplementation with both levels of Bs improved concentrations of blood plasma albumin within the physiological range reported for goats [42]. Blood plasma albumin is a small molecular weight protein that plays a crucial osmoregulatory role in different biological systems. Thus, the improvement in blood plasma albumin of Bs supplemented goats might have positive effects on milk production by maintaining fluid equilibrium during lactation and by increasing water mobilization to the mammary gland as one of the adaptive mechanisms during lactation period [1].

Interestingly, the increased milk production in Bs-treated goats was not associated with negative effects of Bs on fat metabolism (increased NEFAs and BHB) and/or energy balance of goats, as indicated by the unchanged fat-protein ratio (increased ratio indicates 
NEB [5,43]). Moreover, a high proportion of energy was directed to milk production, as indicated by the increased values of NEL in Bs-treated goats. These results highlight the efficient energy utilization by Bs-treated goats, which had lower plasma glucose concentrations without negative effects on body weight, feed intake, metabolism and/or energy status. These findings are in accordance with those previously reported by El-Azrak et al. [1], in which supplementing transitioning goats with $a$ blend of cinnamon, thyme, and peppermint essential oils (a blend rich in terpenoids as active components) has been found an effective intervention to improve milk production, ECM, and NEL, especially during the first three weeks of lactation, mainly by modulating insulin/glucose system during the transition period [1]. Similar effects on milk production, metabolism, and energy status were reported with different phytogenic feed additives [42,44]. This energy homeostasis observed in Bstreated goats could be also due to the antihyperglycemic activity of Bs active components, such as $\alpha$ - and $\beta$-amyrin and boswellic acid [23]. Boswellic acid prevents type 1 and type 2 diabetes mellitus by suppressing the expression of proinflammatory cytokines [9]. Such actions are essential for maintaining sufficient glucose uptake by peripheral tissues and energy homeostasis because transitioning dairy animals express a type of tissue insulin resistance as an adaptive mechanism for milk production.

\section{Conclusions}

Complying with the requirements to maintain health and welfare of farm animals during the production process, supplementing lactating goats in the transition period with Bs resin at a dose of $2 \mathrm{~g} / \mathrm{goat} /$ day can be an effective intervention that positively affects metabolism, udder and uterus health, colostrum IgM content, and milk yield due to its antioxidant and anti-inflammatory activities. These effects were mediated by different active components detected in the Bs resin, mainly terpenes and sterols. Given the economic costs and the farm practice, Bs supplementation can be applied from week two prepartum until week five postpartum, as the most positive effects on goats' performance and health were observed throughout this period.

Author Contributions: Conceptualization, N.M.H. and Y.A.S.; methodology, N.M.H., Y.A.S., A.S.M.; software, N.M.H.; validation, N.M.H., S.M.S.; formal analysis, N.M.H.; data curation, N.M.H.; writing—original draft preparation, N.M.H.; writing—review and editing, N.M.H., S.M.S. All authors have read and agreed to the published version of the manuscript.

Funding: This research received no external funding.

Institutional Review Board Statement: All procedures and experimental protocols were approved by the Declaration of Pharmaceutical and Fermentation Industries Development Center and approved by the Institutional Animal Care and Use Committee (IAUCUs) of SRTA-city (protocol code: IAUCU \#37-6F-1021).

Informed Consent Statement: Not applicable.

Data Availability Statement: The data presented in this study are available on request from the corresponding author. The data are not publicly available because of privacy.

Conflicts of Interest: The authors declare no conflict of interest.

\section{References}

1. El-Azrak, K.M.; Morsy, A.S.; Soltan, Y.; Hashem, N.M.; Sallam, S.M. Impact of specific essential oils blend on milk production, serum biochemical parameters and kid performance of goats. Anim. Biotechnol. 2021, 1-9. [CrossRef]

2. Sundrum, A. Metabolic disorders in the transition period indicate that the dairy cows' ability to adapt is overstressed. Animals 2015, 5, 978-1020. [CrossRef] [PubMed]

3. Moyes, K. Triennial Lactation Symposium: Nutrient partitioning during intramammary inflammation: A key to severity of mastitis and risk of subsequent diseases? J. Anim. Sci. 2015, 93, 5586-5593. [CrossRef]

4. Braga Paiano, R.; Becker Birgel, D.; Birgel, E.H., Jr. Uterine involution and reproductive performance in dairy cows with metabolic diseases. Animals 2019, 9, 93. [CrossRef]

5. Hashem, N.M.; El-Zarkouny, S.Z. Metabolic attributes, milk production and ovarian activity of ewes supplemented with a soluble sugar or a protected-fat as different energy sources during postpartum period. Ann. Anim. Sci. 2017, 17, 229-240. [CrossRef] 
6. Esposito, G.; Irons, P.C.; Webb, E.C.; Chapwanya, A. Interactions between negative energy balance, metabolic diseases, uterine health and immune response in transition dairy cows. Anim. Reprod. Sci. 2014, 144, 60-71. [CrossRef] [PubMed]

7. Bradford, B.; Yuan, K.; Farney, J.; Mamedova, L.; Carpenter, A. Invited review: Inflammation during the transition to lactation: New adventures with an old flame. J. Dairy Sci. 2015, 98, 6631-6650. [CrossRef] [PubMed]

8. Iram, F.; Khan, S.A.; Husain, A. Phytochemistry and potential therapeutic actions of Boswellic acids: A mini-review. Asian Pac. J. Trop. Biomed. 2017, 7, 513-523. [CrossRef]

9. Ammon, H. Boswellic extracts and 11-keto-ß-boswellic acids prevent type 1 and type 2 diabetes mellitus by suppressing the expression of proinflammatory cytokines. Phytomedicine 2019, 63, 153002. [CrossRef]

10. Birkner, K.M. Boswellia, the pain herb. Pain Stress Publ. 2006, 1, 60-61.

11. Franz, C.; Baser, K.; Windisch, W. Essential oils and aromatic plants in animal feeding-A European perspective. A review. Flavour Fragr. J. 2010, 25, 327-340. [CrossRef]

12. Ismail, I.E.; Abdelnour, S.A.; Shehata, S.A.; El-Hack, A.; Mohamed, E.; El-Edel, M.A.; Taha, A.E.; Schiavitto, M.; Tufarelli, V. Effect of dietary Boswellia serrata resin on growth performance, blood biochemistry, and cecal microbiota of growing rabbits. Front. Vet. Sci. 2019, 6, 471. [CrossRef] [PubMed]

13. National Research Council. Nutrient Requirements of Small Ruminants: Sheep, Goats, Cervids, and New World Camelids; The National Academies Press: Washington, DC, USA, 2007.

14. Alderman, G. Prediction of the energy value of compound feeds. Recent Adv. Anim. Nutr. 1985, 285.

15. Feldman, B.F.; Zinkl, J.G.; Jain, N.C. Schalm's Veterinary Hematology; Blackwell: Hoboken, NJ, USA, 2000.

16. Calder, P.C. Immunological parameters: What do they mean? J. Nutr. 2007, 137, 773S-780S. [CrossRef] [PubMed]

17. Kawahara, E.; Ueda, T.; Nomura, S. In vitro phagocytic activity of white-spotted char blood cells after injection with Aeromonas salmonicida extracellular products. Fish Pathol. 1991, 26, 213-214. [CrossRef]

18. Rainger, G.; Rowley, A. Antibacterial activity in the serum and mucus of rainbow trout, Oncorhynchus mykiss, following immunisation with Aeromonas salmonicida. Fish. Shellfish Immunol. 1993, 3, 475-482. [CrossRef]

19. Dulin, A.; Paape, M.; Wergin, W. Differentiation and enumeration of somatic cells in goat milk. J. Food Prot. 1982, 45, 435-439. [CrossRef] [PubMed]

20. Wiggans, G.; Shook, G. A lactation measure of somatic cell count. J. Dairy Sci. 1987, 70, 2666-2672. [CrossRef]

21. Hashem, N.; El-Zarkouny, S.; Taha, T.; Abo-Elezz, Z. Oestrous response and characterization of the ovulatory wave following oestrous synchronization using PGF2 $\alpha$ alone or combined with GnRH in ewes. Small Rumin. Res. 2015, 129, 84-87. [CrossRef]

22. Mateus, L.; Da Costa, L.L.; Carvalho, H.; Serra, P.; Robalo Silva, J. Blood and intrauterine leukocyte profile and function in dairy cows that spontaneously recovered from postpartum endometritis. Reprod. Domest. Anim. 2002, 37, 176-180. [CrossRef]

23. National Research Council. Nutrient Requirements of Dairy Cattle, 7th ed.; The National Academies Press: Washington, DC, USA, 2001.

24. Hashem, N.; Abu-Tor, E.; Abo-Elezz, Z.; Latif, M. Relevance of antioxidant vitamin supplementation for improvement of milk production, milk quality and energy status of lactating ewes. Small Rumin. Res. 2019, 177, 153-159. [CrossRef]

25. Ammon, H. Modulation of the immune system by Boswellia serrata extracts and boswellic acids. Phytomedicine 2010, 17, 862-867. [CrossRef]

26. Hamidpour, S.; Hamidpour, M.; Shahlari, M.; Hamidpour, R. Chemistry, pharmacology and medicinal property of frankincense (Boswellia Species): From the selection of traditional applications to the novel phytotherapy for the prevention and treatment of serious diseases. Glob. J. Med. Res. 2015, 15, 1-9.

27. Roy, N.K.; Parama, D.; Banik, K.; Bordoloi, D.; Devi, A.K.; Thakur, K.K.; Padmavathi, G.; Shakibaei, M.; Fan, L.; Sethi, G. An update on pharmacological potential of boswellic acids against chronic diseases. Int. J. Mol. Sci. 2019, 20, 4101. [CrossRef] [PubMed]

28. Hashem, N.; El-Zarkouny, S. Postpartum associated metabolism, milk production and reproductive efficiency of Barki and Rahmani subtropical fat-tailed Breeds. Asian J. Anim. Vet. Adv. 2016, 11, 184-189. [CrossRef]

29. Yu, Z.-L.; Peng, Y.-L.; Wang, C.; Cao, F.; Huo, X.-K.; Tian, X.-G.; Feng, L.; Ning, J.; Zhang, B.-J.; Sun, C.-P. Alismanoid A, an unprecedented 1, 2-seco bisabolene from Alisma orientale, and its protective activity against $\mathrm{H}_{2} \mathrm{O}_{2}$-induced damage in SH-SY5Y cells. New J. Chem. 2017, 41, 12664-12670. [CrossRef]

30. Zheng, Y.; Huang, W.; Yoo, J.-G.; Ebersole, J.L.; Huang, C.B. Antibacterial compounds from Siraitia grosvenorii leaves. Nat. Prod. Res. 2011, 25, 890-897. [CrossRef] [PubMed]

31. Skalicka-Woźniak, K.; Grzegorczyk, A.; Świątek, Ł.; Walasek, M.; Widelski, J.; Rajtar, B.; Polz-Dacewicz, M.; Malm, A.; Elansary, H.O. Biological activity and safety profile of the essential oil from fruits of Heracleum mantegazzianum Sommier \& Levier (Apiaceae). Food Chem. Toxicol. 2017, 109, 820-826.

32. Soka, S.; Alam, H.; Boenjamin, N.; Agustina, T.W.; Suhartono, M.T. Effect of Sauropus androgynus leaf extracts on the expression of prolactin and oxytocin genes in lactating BALB/C Mice. Lifestyle Genom. 2010, 3, 31-36. [CrossRef]

33. Soltan, Y.; Morsy, A.; Hashem, N.; Sallam, S. Boswellia sacra resin as a phytogenic feed supplement to enhance ruminal fermentation, milk yield, and metabolic energy status of early lactating goats. Anim. Feed Sci. Technol. 2021, 277, 114963. [CrossRef]

34. Al-Harrasi, A.; Rehman, N.U.; Khan, A.L.; Al-Broumi, M.; Al-Amri, I.; Hussain, J.; Hussain, H.; Csuk, R. Chemical, molecular and structural studies of Boswellia species: $\beta$-Boswellic Aldehyde and 3-epi-11 $\beta$-Dihydroxy BA as precursors in biosynthesis of boswellic acids. PLoS ONE 2018, 13, e0198666. [CrossRef] [PubMed] 
35. Nusier, M.K.; Bataineh, H.N.; Bataineh, Z.M.; Daradka, H.M. Effect of frankincense (Boswellia thurifera) on reproductive system in adult male rat. J. Health Sci. 2007, 53, 365-370. [CrossRef]

36. Ahangarpour, A.; Heidari, H.; Fatemeh, R.A.A.; Pakmehr, M.; Shahbazian, H.; Ahmadi, I.; Mombeini, Z.; Mehrangiz, B.H. Effect of Boswellia serrata supplementation on blood lipid, hepatic enzymes and fructosamine levels in type 2 diabetic patients. J. Diabetes Metab. Disord. 2014, 13, 29. [CrossRef]

37. Elmetwally, M.A. Uterine involution and ovarian activity in postpartum Holstein dairy cows. A review. J. Vet. Healthc. 2018, 1, 29. [CrossRef]

38. Chapinal, N.; LeBlanc, S.; Carson, M.; Leslie, K.; Godden, S.; Capel, M.; Santos, J.; Overton, M.; Duffield, T. Herd-level association of serum metabolites in the transition period with disease, milk production, and early lactation reproductive performance. J. Dairy Sci. 2012, 95, 5676-5682. [CrossRef] [PubMed]

39. Yeo, S.K.; Ali, A.Y.; Hayward, O.A.; Turnham, D.; Jackson, T.; Bowen, I.D.; Clarkson, R. $\beta$-Bisabolene, a sesquiterpene from the essential oil extract of opoponax (Commiphora guidottii), exhibits cytotoxicity in breast cancer cell lines. Phytother. Res. 2016, 30, 418-425. [CrossRef]

40. Ahmad, M.; Hidayanty, H.; As'ad, S.; Arifuddin, S.; Usman, A.N. The effect of biscuit made with mung beans (Vigna radiata), and star gooseberry (Sauropus androgynous) leaves on infant weight. Eur. J. Mol. Clin. Med. 2021, 7, 3725-3736.

41. Suprayogi, A. Studies on the Biological Effects of Sauropus androgynus (L.) Merr: Effects on Milk Production and the Possibilities of Induced Pulmonary Disorder in Lactating Sheep; Cuvillier: Göttingen, Germany, 2000.

42. El-Essawy, A.M.; Anele, U.; Abdel-Wahed, A.; Abdou, A.R.; Khattab, I. Effects of anise, clove and thyme essential oils supplementation on rumen fermentation, blood metabolites, milk yield and milk composition in lactating goats. Anim. Feed Sci. Technol. 2021, 271, 114760. [CrossRef]

43. Hashem, N.M.; El-Zarkouny, S.Z. Effect of short-term supplementation with rumen-protected fat during the late luteal phase on reproduction and metabolism of ewes. J. Anim. Physiol. Anim. Nutr. 2014, 98, 65-71. [CrossRef]

44. Kholif, A.E.; Olafadehan, O.A. Essential oils and phytogenic feed additives in ruminant diet: Chemistry, ruminal microbiota and fermentation, feed utilization and productive performance. Phytochem. Rev. 2021, 1-22. [CrossRef] 